\title{
PENTINGNYA PEMAHAMAN SOSIAL PSIKOLOGIS DALAM PEMBINAAN ANAK PANTI ASUHAN Sebuah Studi Kasus di Panti Asuhan Kristen Eunike Semarang
}

\author{
Greta Vidya Paramita \\ Jurusan Psikologi, Fakultas Psikologi, Bina Nusantara University \\ Jln. Kemanggisan Ilir III No. 45, Kemanggisan, Palmerah, Jakarta Barat 11480 \\ gretavidya@binus.edu
}

\begin{abstract}
This study aims to discuss the importance of social psychological understanding of coaching children in the orphanage. Coaching is the business, action, and carried out activities in an efficient and effective way to obtain a better result. Research conducted on 19 subjects in Eunice Christian Orphanage located in the city of Semarang. The research method used in this study is a qualitative method, namely through psychological examinations using diagnostic tool Draw A Man (DAM), Baum, and descriptions of themselves in writing. From the results of this study concluded that each foster child has the distinction that needs to be recognized by the head of the orphanage and the caregivers. Psychological understanding of social conditions necessary for development of each child which can be done right on target.
\end{abstract}

Keywords: social psychological care, orphanage

\begin{abstract}
ABSTRAK
Penelitian ini bertujuan untuk membahas pentingnya pemahaman sosial psikologis dalam pembinaan anak panti asuhan. Pembinaan yang dimaksud disini adalah usaha, tindakan, dan kegiatan yg dilakukan secara efisien dan efektif untuk memperoleh hasil yg lebih baik. Penelitian dilakukan terhadap 19 orang subjek di Panti Asuhan Kristen Eunike yang berlokasi di kota Semarang. Metode penelitian yang digunakan dalam penelitian ini adalah dengan metode kualitatif, yaitu melalui pemeriksaan psikologis menggunakan alat diagnosa Draw A Man (DAM), BAUM, dan deskripsi diri secara tertulis. Dari hasil penelitian ini disimpulkan bahwa setiap anak asuh memiliki perbedaan yang perlu dikenali oleh kepala panti dan pengasuh. Pemahaman terhadap kondisi sosial psikologis setiap anak diperlukan agar pembinaan yang dilakukan dapat tepat sasaran.
\end{abstract}

Kata kunci: pembinaan sosial psikologis, panti asuhan 


\section{PENDAHULUAN}

Pada hakekatnya, setiap manusia memiliki hirarkhi kebutuhan seperti yang tertuang dalam teori Abraham Maslow. Dalam teori Maslow disebutkan bahwa kebutuhan untuk mendapatkan kasih sayang sebagai salah satu kebutuhan psikologis yang lebih mendasar daripada kebutuhan akan penghargaan maupun aktualisasi diri (Lahey, 2009). Kebutuhan akan kasih sayang ini biasanya pertama kali didapatkan seorang anak dalam interaksinya dengan lingkungan terdekatnya, yaitu keluarga khususnya orang tua. Namun sayangnya kondisi ideal seperti ini tidak selalu terjadi. Tidak jarang, kebutuhan dasar seorang anak untuk mendapatkan kasih sayang terabaikan karena berbagai kondisi yang dihadapi oleh keluarga. Kondisi perekonomian keluarga yang serba terbatas adalah salah satu kondisi yang dapat mempengaruhi kualitas kebersamaan orang tua dengan anak di mana orang tua terlalu sibuk bekerja dan kurang memiliki waktu untuk mencurahkan perhatian pada anak, meskipun kondisi ini tidak menjadi syarat mutlak tidak terpenuhinya kasih sayang pada anak. Kondisi keluarga yang berkecukupan pun tidak menjamin perhatian yang diberikan kepada anak terpenuhi dengan baik bila memang orang tua tidak memprioritaskan pemberian perhatian kepada anak. Selain kondisi perekonomian keluarga, kurangnya kasih sayang pada seorang anak terkadang juga terjadi karena tidak adanya figur ayah, ibu, ataupun keduanya yang dilatarbelakangi oleh berbagai alasan seperti kematian, perceraian, bekerja di luar kota, dan lain sebagainya.

Dengan berbagai latar belakang ketidakidealan ini, panti asuhan menjadi sebuah lembaga yang memiliki misi untuk memberikan penghidupan yang lebih baik kepada anak-anak ini. Panti Asuhan Kristen (PAK) Eunike adalah salah satu diantara ribuan panti asuhan yang ada di Indonesia yang didirikan dengan misi sosial untuk mengentaskan anak-anak yang berasal dari keluarga yang memiliki keterbatasan secara ekonomi maupun keluarga yang tidak lengkap, entah sebagai yatim, piatu, ataupun yatim piatu. Berdasarkan data dari Kementerian Sosial RI (Sudradjat, 2008), diperkirakan terdapat 5.000 hingga 8.000 panti asuhan di seluruh Indonesia dan 99\% diantaranya dikelola oleh masyarakat, terutama organisasi agama. PAK Eunike didirikan di kota Semarang pada masa penjajahan Belanda dan sempat vakum pada masa penjajahan Jepang sebelum akhirnya mula beroperasi kembali pada tahun 1950 ketika Indonesia sudah merdeka. Saat ini, PAK Eunike mengasuh 30 anak yang terdiri dari 21 anak perempuan dan 9 anak laki-laki. Mereka mayoritas berasal dari kota-kota di radius sekitar 200 KM dari Semarang. Pada umumnya anak-anak diasuh di panti asuhan ini hingga mereka lulus Sekolah Menengah Kejuruan (SMK) dan kemudian dicarikan pekerjaan. Beberapa di antara mereka bahkan berkuliah dengan melanjutkan ke panti asuhan lainnya yang memang membiayai hingga kuliah.

PAK Eunike berdiri di atas lahan seluas $7000 \mathrm{~m} 2$ dan terdapat beberapa cottage yang dipisahkan berdasarkan jenis kelamin, dapur, ruang makan, kapel, ruang serba guna,dan ruang kantor panti. Setiap cottage diisi 5 hingga 6 orang anak, dimana di dalam setiap cottage ada anak yang lebih senior yang bertanggung jawab untuk membimbing temannya yang lebih muda. Dengan sistem mentoring seperti ini, diharapkan terjadi ikatan diantara mereka layaknya kakak-beradik. Panti asuhan ini dikepalai oleh seorang ibu dan seorang bapak pengasuh yang setiap harinya membimbing mereka. Setiap harinya anak-anak bangun pagi dan harus mengerjakan berbagai pekerjaan domestik mereka masing-masing seperti membersihkan kamar, mencuci pakaian, menyetrika pakaian, dan membersihkan lingkungan sekitar cottage mereka.

Penelitian Sudrajat (2008) menemukan bahwa pengasuhan di panti asuhan masih sangat kurang dan panti lebih berfokus pada pemenuhan kebutuhan kolektif, khususnya kebutuhan materi sehari-hari sementara kebutuhan emosional dan pertumbuhan anak-anak tidak dipertimbangkan. Sekali anak-anak memasuki panti asuhan, mereka diharapkan untuk tinggal di sana sampai lulus dari SMA kecuali mereka melahggar peraturan atau tidak berprestasi di sekolah. Dengan demikian panti asuhan sering kali hanya memberikan akses pendidikan saja namun pertumbuhan pribadi anak kurang mendapatkan perhatian secara khusus. 
Di PAK Eunike sendiri sebetulnya sudah memiliki keinginan untuk menjadi fasilitator pertumbuhan pribadi anak, hal ini terbukti dari berbagai kegiatan yang memang disiapkan untuk mengasah pribadi mereka seperti sistem mentoring dari yang lebih senior kepada yang lebih yunior, tugas piket, siraman kerohanian, dan berbagai kegiatan lainnya. Namun dalam kenyataannya hal-hal baik yang sudah diterapkan oleh ibu kepala panti terdahulu ini kurang dimonitor secara intensif. Keterbatasan tingkat pendidikan dan pemahaman pengasuh terhadap fungsi pengasuhan dan pembinaannya sendiri kurang sehingga tidak ada konsep atau pola tertentu yang memang dirancang untuk membekali anak-anak ini.

Kehidupan di panti berjalan lancar dan tidak ada masalah yang berarti hingga pada medio 2010 ketika bapak pengasuh panti mengalami kecelakaan lalu lintas dan meninggal dunia. Pengasuh panti yang telah bekerja di PAK Eunike selama 16 tahun ini kemudian digantikan oleh seorang bapak pengasuh panti baru yang datang ke panti bersama istrinya yang kemudian menjadi juru masak di panti. Dengan bimbingan dari ibu kepala panti, pengasuh yang belum berpengalaman ini mulai belajar banyak hal. Namun disaat pengasuh masih dalam proses belajar, ibu kepala panti meninggal dunia karena sakit dan juga usia lanjut. Pada saat beliau meninggal, beliau telah bekerja di PAK Eunike selama 20 tahun dan kepergian beliau hanya berjarak kira-kira setengah tahun dari kepergian bapak pengasuh panti. Dalam kondisi vakum kepemimpinan ini, bapak pengasuh panti beserta istri menjadi pemegang peranan di panti. Tak lama kemudian direkrutlah seorang ibu kepala panti yang baru namun keadaan panti tidak menjadi semakin baik karena perbedaan gaya pengasuhan antara bapak pengasuh dengan ibu kepala panti. Bapak pengasuh menerapkan pola kepemimpinan laissez-faire, sedangkan ibu kepala panti menggunakan pendekatan otoritarian. Gaya kepemimpinan laissez-faire, ditandai dengan pengarahan yang tidak terlalu banyak dan bawahan diberikan sebanyak mungkin kebebasan http://www.essortment.com/styles-leadership).

Pada gaya kepemimpinan ini, seluruh otoritas atau kekuasaan diberikan kepada bawahan dan mereka harus menentukan gol, membuat keputusan, dan menyelesaikan masalah mereka sendiri. Sedangkan gaya kepemimpinan otoriter ditandai dengan kekuasaan penuh pada pemimpin. Pemimpin pada gaya kepemimpinan ini sering kali idak mempercayai bawahannya dan tidak mau berdiskusi dengan orang-orang yang ada dibawahnya. Perbedaan gaya kepemimpinan ini pada akhirnya berdampak pada penerimaan anak-anak terhadap ibu kepala panti maupun bapak pengasuh. Kepala panti dianggap terlalu kejam dan tidak mengerti kebutuhan mereka, berlawanan dengan bapak pengasuh yang dianggap baik karena mau menuruti segala kemauan mereka. Kedisiplinan yang selama ini diterapkan oleh almarhumah kepala panti sebelumnya menjadi luntur. Tidak ada lagi semangat kebersamaan yang tadinya diajarkan kepada mereka karena berbagai kebiasaan seperti makan bersama ditiadakan oleh pengasuh sedangan kepala panti yang baru tidak dapat berbuat banyak karena ia baru bekerja di panti tersebut belakangan setelah pengasuh panti. Selain itu, dengan pendekatannya yang populis, pengasuh panti berhasil membuat anak-anak menjauh dari ibu kepala panti.

Atas dasar kondisi ini, maka ketua yayasan PAK Eunike meminta kepada peneliti untuk melakukan pemeriksaan psikologis terhadap seluruh penghuni panti dan memberikan masukan tentang pendekatan yang tepat terhadap mereka. Berdasarkan latar belakang seperti yang telah diuraikan di atas, maka ingin diketahui bagaimana pembinaan anak panti asuhan yang tepat.

\section{METODE PENELITIAN}

Metode penelitian yang dipakai adalah metode penelitian kualitatif, yaitu penelitian yang menghasilkan dan mengolah data yang sifatnya deskriptif, seperti transkripsi, wawancara, lembar observasi, gambar, foto, rekaman video, dan lain sebagainya (Poerwandari, 2001). Penelitian kualitatif 
bersifat ilmiah, yang berarti studi dilakukan terhadap suatu fenomena dalam situasi dimana fenomena tersebut ada atau dengan kata lain dapat dikatakan bahwa penelitian yang dilakukan berorientasi pada penemuan dan tidak ada manipulasi pada variable-variablenya (Patton, 1990 dalam Poerwandari, 2001). Dengan demikian peneliti menjadi lebih bebas unruk berpikir dan tidak membatasi pola pikirnya pada upaya untuk menolak atau menerima suatu hipotesa,namun berusaha untuk memahami bagaimana fenomena tersebut tampil (Poerwandari, 2001).

Dalam penelitian ini, peneliti menggunakan alat tes kepribadian proyektif, yaitu DAM, BAUM, deskripsi diri secara tertulis, dan wawancara secara lisan. Selain pemeriksaan terhadap subjek, peneliti juga melakukan wawancara kepada pengasuh, juru masak, dan juga kepala panti secara terpisah satu sama lain. Pemeriksaan psikologis ini dilakukan untuk mendapatkan profil umum subjek sehingga dapat diberikan saran pembinaan yang tepat. Jumlah subjek dalam penelitian ini adalah 19 anak dengan rentang usia 12-20 tahun. Pemeriksaan dilakukan secara klasikal di ruang makan pk. 16.00 sampai dengan 18.30 pada tanggal 27 November 2010.

\section{HASIL DAN PEMBAHASAN}

Berikut rangkuman dari data diri subjek:

Tabel 1 Penghuni Panti Asuhan Eunike

\begin{tabular}{clllll}
\hline No. & Subjek & Jenis Kelamin & $\begin{array}{c}\text { Usia } \\
\text { (tahun) }\end{array}$ & $\begin{array}{c}\text { Tahun Masuk } \\
\text { Panti }\end{array}$ & Alasan \\
\hline 1. & HT & Perempuan & 20 & 2005 & Ekonomi lemah \\
2. & AN & Perempuan & 18 & 2005 & Ekonomi lemah \\
3. & EP & Perempuan & 18 & 2005 & Ekonomi lemah \\
4. & KR & Laki-laki & 18 & 2005 & Ekonomi lemah \\
5. & ER & Perempuan & 17 & 2005 & Ekonomi lemah \\
6. & IS & Perempuan & 17 & 2005 & Ekonomi lemah \\
7. & HM & Perempuan & 16 & 2008 & Ekonomi lemah \\
8. & YC & Laki-laki & 16 & 2007 & Ekonomi lemah \\
9. & ME & Perempuan & 16 & 2007 & Ekonomi lemah \\
10. & NH & Perempuan & 15 & 2007 & Ekonomi lemah \\
11. & RY & Perempuan & 15 & 2007 & Ekonomi lemah \\
12. & MK & Perempuan & 14 & 2007 & Ekonomi lemah \\
13. & AR & Laki-laki & 13 & 2010 & Ekonomi lemah \\
14. & NA & Perempuan & 13 & 2009 & Ekonomi lemah \\
15. & HE & Perempuan & 13 & 2009 & Ekonomi lemah \\
16. & TA & Perempuan & 13 & 2006 & Ekonomi lemah \\
17. & ET & Perempuan & 12 & 2009 & Ekonomi lemah \\
18. & ND & Laki-laki & 12 & 2009 & Ekonomi lemah \\
19. & AM & Perempuan & 12 & 2008 & Ekonomi lemah \\
\hline
\end{tabular}

Gambaran data ini sejalan dengan Sudrajat (2008) yang menyatakan bahwa hanya ada persentasi yang sangat kecil untuk anak-anak di panti asuhan yang benar-benar yatim piatu (6\%) dan 90\% di antaranya memiliki salah satu atau kedua orang tua. Kebanyakan anak-anak ditempatkan di panti asuhan oleh keluarganya yang mengalami kesulitan ekonomi dan juga secara sosial dalam konteks tertentu, dengan tujuan untuk memastikan anak-anak mereka mendapatkan pendidikan.

Secara umum hasil pemeriksaan psikologis menunjukkan bahwa para subjek memiliki kebutuhan akan afeksi yang cukup menonjol. Kebutuhan akan afeksi yang menonjol ini dapat terjadi karena beberapa hal antara lain kurangnya kasih sayang dari orang tua karena kondisi ekonomi 
keluarga yang lemah sehingga frekuensi komunikasi maupun pertemuan dengan anak menjadi rendah. Dalam sebulan, belum tentu orang tua akan datang mengunjungi anak-anak mereka di panti. Selain itu, kondisi di panti yang memiliki 30 orang anak dengan hanya 1 pengasuh dan 1 kepala panti asuhan berdampak pada tidak tercukupinya kebutuhan akan afeksi dari setiap anak. Berdasarkan hasil wawancara yang dilakukan terhadap subjek maupun kepala panti, diketahui bahwa saat ini belum ada kegiatan kumpul bersama yang secara khusus dilakukan sebagai wadah konseling bagi para subjek. Subjek ME menyampaikan bahwa ketika ia memiliki 'unek-unek' dan ingin bercerita, tidak ada yang menjadi tempat curahan hatinya. Selain karena hubungan yang tidak dekat dengan kepala panti karena beliau adalah orang baru, ia merasa bahwa kepala panti adalah orang yang kurang hangat sehingga terciptalah sebuah jarak diantara mereka. Sedangkan bapak pengasuh dan ibu juru masak, dianggapnya kurang mampu menjadi sosok orang tua yang sabar mendengarkan keluhan mereka.

Bila ditilik dari teori perkembangan, friksi yang terjadi antara pihak otoritas panti dengan anak-anak dapat dipahami sebagai bagian dari masa perkembangan subjek. Dari data yang terkumpul diketahui bahwa mayoritas subjek berada dalam tahapan perkembangan remaja. Pada masa remaja, kondisi emosi cenderung labil. Tanpa provokasi, suasana hati yang naik dan turun serta ketidakmampuan mereka untuk mengekspresikan emosi secara tepat dapat membuat orang-orang terdekat di sekitarnya menjadi sasaran pelampiasan emosinya (Santrock, 2002). Hal ini diperparah dengan adanya konflik diantara kepala panti dan pengasuh sehingga provokasi dari pengasuh menjadikan hubungan mereka dengan kepala panti menjadi semakin jauh.

Selain kebutuhan afeksi yang kurang terpenuhi, hasil pemeriksaan psikologis juga menunjukkan bahwa para subjek kurang mampu bersikap hangat kepada orang lain. Ketika bertemu orang baru, para subjek cenderung menunjukkan sikap menjaga jarak dan terkesan cuek. Ciri remaja lainnya yang muncul secara signifikan dalam pemeriksaan adalah perilaku mencari perhatian terutama dari subjek perempuan. Beberapa subjek perempuan ingin menjadi pusat perhatian, namun disisi lain mereka sebetulnya kurang percaya diri sehingga pada akirnya mereka hanya berani berpendapat ketika temannya juga berbicara.

Dari keseluruhan pemeriksaan, terdapat dua orang subjek yang menunjukkan hasil yang signifikan dan berbeda dari kelompoknya. Salah satu subjek, yaitu ER menunjukkan agresivitas yang terlihat jelas dalam hasil tes. Dari hasil wawancara dengan kepala panti, diketahui bahwa subjek memang memiliki masa lalu yang tidak menyenangkan dimana ia dan ibunya ditinggalkan oleh ayahnya yang tidak diketahui keberadaannya. Dalam keseharian subjek menampilkan perilaku sebagai seorang anak yang penurut namun ketika tidak dalam pengawasan ia menjadi seorang anak yang lepas kendali. Ia terkadang pulang di atas jam malam yang ditentukan dan memanjat pagar panti. Sedangkan subjek lainnya yang bernama RY menunjukkan sifat kekanak-kanakan dan adaptasi yang kurang baik. RY juga tidak menunjukkan minat untuk menjalin relasi dengan orang lain. Untuk mengatasi hal ini, kepala panti akhirnya memutuskan bahwa kedua subjek harus tinggal bersama-sama dengan ibu kepala panti di cottage ibu kepala panti dan mendapatkan pengawasan yang lebih ketat agar perilaku ER yang kurang baik dapat berubah, sedangkan RY dapat menjadi seorang anak yang lebih memiliki minat sosial. Pendekatan yang dilakukan terhadap kedua subjek ini sudah cukup baik, namun kepala panti tetap perlu menjaga objektivitasnya sehingga tidak menjadi pilih kasih ataupun menimbulkan kecemburuan pada anak-anak lainnya.

Dari hasil wawancara diketahui bahwa aktivitas harian anak-anak di panti ini, antara lain bangun pagi, membersihkan area sekitar cottage, mencuci dan menyetrika baju mereka. Pada jam makan, mereka harus bersama-sama berkumpul di ruang makan dan makan bersama dengan terlebih dahulu dibuka dengan doa. Aktivitas makan dilakukan bersama-sama dengan tujuan agar makanan terdistribusi secara adil dan mereka belajar untuk saling berbagi dan melayani. Setelah makan, masing-masing dari mereka harus mencuci piring mereka dan bergotong-royong membersihkan ruang makan. Untuk kegiatan ibadah di kapel biasanya dilakukan minimal dua minggu 1 kali dan ibadah hari Minggu dilakukan di gereja di sekitar lokasi panti asuhan. Lokasi sekolah yang jauh 
menyebabkan kegiatan pembinaan ekstra kurikuler seperti menjahit, olah raga, kerajinan tangan, dan lain sebagainya tidak dapat dilakukan karena ketika mereka pulang hari sudah cukup larut malam. Kegiatan ekstra kurikuler akhirnya hanya dapat dilakukan di sekolah. Meski demikian, pihak panti sebetulnya tetap perlu menyelenggarakan kegiatan-kegiatan yang dapat membangun semangat kebersamaan di antara mereka. Kerjasama, koordinasi, dan komunikasi di antara subjek menjadi halhal yang perlu mendapatkan penguatan, karena dengan adanya semangat kebersamaan ini maka subjek akan merasa bahwa ia pun memiliki sebuah keluarga dip anti itu sehingga ia menjadi lebih bahagia.

Selama ini pola pembinaan yang dilakukan terhadap anak-anak adalah dengan kekeluargaan dan mereka yang lebih dewasa membina yang lebih muda. Pola seperti ini ada di sebagian besar panti asuhan yang ada di Indonesia. Hal ini sesuai dengan Sudrajat (2008) bahwa hampir tidak ada asesmen tentang adanya kebutuhan pengasuhan anak-anak baik sebelum, selama, maupun selepas mereka meninggalkan panti asuhan.Kegiatan pengasuhan lebih banyak dilakukan antar anak-anak itu sendiri, sedangkan peran serta pengasuh justru menjadi kurang menonjol. Pengasuh dan kepala panti perlu memberikan upaya lebih untuk memahami bahwa setiap anak memiliki tingkat kematangan diri yang berbeda-beda (Landis \& Landis, 1970). Kondisi ini menyebabkan pendekatan yang diberikan kepada setiap anak-anak berbeda-beda. Subjek yang usianya lebih tua dapat diberikan tanggung jawab yang lebih besar dari pada subjek yang lebih muda. Selain itu pihak panti perlu memikirkan adanya layanan pusat konseling sebagai bagian dari pembinaan psikologi anak asuh.

\section{PENUTUP}

Dari penelitian ini dapat disimpulkan bahwa pengasuhan di panti asuhan tidak hanya melibatkan kognitif saja, namun perlu pembinaan holistik yang menyentuh ranah afektif juga. Perlu diingat pula bahwa anak-anak di panti asuhan tidak hanya memerlukan pendidikan dari lembaga formal, namun mereka juga perlu mendapatkan berbagai pelatihan untuk mengasah mereka menjadi pribadi yang siap masuk ke masyarakat. Pada akhirnya anak-anak ini tidak akan terus ada di panti asuhan dan mereka harus siap untuk hidup mandiri sehingga diharapkan keberadaan mereka di panti dapat membantu pembentukan karakter mereka. Panti asuhan perlu secara khusus melakukan asesmen secara berkala untuk mengetahui kondisi psikologis anak asuh. Dengan mengetahui kondisi psikologis anak asuh, pendekatan yang dilakukan dapat menjadi lebih tepat. Sedangkan bagi pengasuh, kepala panti asuhan, maupun staff panti lainnya perlu pemahaman sosial psikologis dalam membina anak panti asuhan. Tidak cukup hanya pemenuhan kebutuhan secara fisik saja, namun yang lebih penting adalah bagaimana pihak otoritas panti dapat memfasilitasi pengembangan kepribadian setiap anak. Pola pembinaan yang dilakukan di panti asuhan juga perlu dievaluasi secara berkala untuk melihat efektivitas dan kualitas dari pembinaan yang dilakukan.

\section{DAFTAR PUSTAKA}

(2011). Leadership styles, diakses 25 Februari 2011 dari http://www.essortment.com/stylesleadership-36149.html

Lahey, B. (2009). Psychology: an introduction $10^{\text {th }}$ Ed. New York: McGraw-Hill

Landis, J. T. \& Landis, M. G. (1970). Personal adjustment, marriage, and family living $5^{\text {th }}$. Ed. New Jersey: Prentice Hall

Poerwandari, E. K. (2001). Pendekatan kualitatif dalam penelitian psikologi. Jakarta: Lembaga Pengembangan dan Pendidikan Psikologi Universitas Indonesia. 
Santrock, J. W. (2002). A topical approach to life-span development international Ed. New York: McGraw-Hill

Sudrajat, T. (2008, 4 Juni). Kurangnya 'pengasuhan' di Panti Asuhan, diakses 25 Februari 2011 dari http://www.depsos.go.id/modules.php?name=News\&file=article\&sid=674

\section{RIWAYAT PENULIS}

Greta Vidya Paramita lahir di kota Semarang pada tanggal 31 Maret 1981. Penulis menyelesaikan pendidikan S1 di Fakultas Psikologi Universitas Kristen Maranatha Bandung pada tahun 2004. Sedangkan pendidikan S2 berhasil diselesaikan di Program Magister Profesi Fakultas Psikolgi Universitas Indonesia dengan mayor Klinis Dewasa pada tahun 2006. Saat ini penulis bekerja sebagai dosen di Fakultas Psikologi Universitas Bina Nusantara. Penulis tergabung dalam organisasi keprofesian Himpunan Psikologi Indonesia wilayah Jakarta (HIMPSI Jaya). 